\title{
Delta FM Jogja's marketing communication strategy in maintaining its existence in the Special Region of Yogyakarta
}

\author{
Evanny Yuwike Permata ${ }^{1}$, Panji Dwi Ashrianto ${ }^{2}$ \\ ${ }^{1,2}$ Department of Communication Science \\ Faculty of Social and Political Sciences, UPN "Veteran" Yogyakarta, Indonesia \\ *Corresponding author, email: evanny.yuwikepermata@gmail.com
}

\begin{abstract}
Article History
Received: 05/07/2021

Revised: $13 / 07 / 2021$

Accepted: 16/07/2021

Published: $30 / 07 / 2021$
\end{abstract}

\begin{abstract}
The intense radio competition in Yogyakarta requires radios to have a strategy in maintaining their existence in this digitalized era. A good marketing communication strategy is needed to attract the attention of both listeners and advertisers. Delta FM radio as a network radio certainly has challenges in competing with other competitor radios in Yogyakarta. Delta FM radio requires the right marketing communication strategy to maintain its existence. This study aims to determine the marketing communication strategy of Delta FM Yogyakarta in maintaining its existence in D.I.Yogyakarta. This study uses Planning theory by Berger, Marketing Communication Mix, and analysis of Segmenting, Targeting, and Positioning (S-T-P). The research method used is descriptive qualitative. The results showed that in determining the marketing communication strategy, Delta FM Yogyakarta carried out three stages, namely the planning stage, the implementation stage, and the evaluation stage. Delta FM uses five stages of marketing communication mix in its implementation, such as Advertising, Sales Promotion, Public Relations, Personal Selling, and Direct Selling. The substance of this research contributes to new policy recommendations for the radio station in developing marketing communication strategies.
\end{abstract}

Keywords: Marketing Communication Strategy, Marketing Communication Mix, Analysis S-T-P, Radio

\section{Introduction}

The development of information and communication technology has a positive and negative impact on the development of the media industry business. The mass media business grows in a complex system and must have great competitiveness to get the audience's attention, time, and support to establish a position and make a profit.

Radio is a testament to the rapid and intense development of the current media business competition. Therefore, the growth of radio in Indonesia is currently increasing. Radio is one of the mass media closely related to the community's needs to provide various kinds of information, education, and entertainment. The main characteristic of radio is auditive, which is consumed by 
the ear or hearing. Thus, because of its auditive nature, it can encourage people to prefer it as one of the mass media that is quickly popular with easy acceptance without requiring special skills (Romli, 2016).

Radio has high flexibility in providing information, besides being the fastest means of conveying information to the public without a complicated process. The information provided is concise, clear, and efficient. The advantage of radio that other media does not have is that it can be enjoyed anywhere and anytime as a medium of information to accompany daily activities such as cooking, driving, studying, relaxing, etc.

According to Nielsen data, radio growth in 10 major cities in Indonesia during the last five years in this third wave experienced the highest increase, reaching $12 \%$ of the average per wave. It proves that there are still many people who are interested in listening to the radio.

\section{GROWTH RADIO IN INDONESIA}

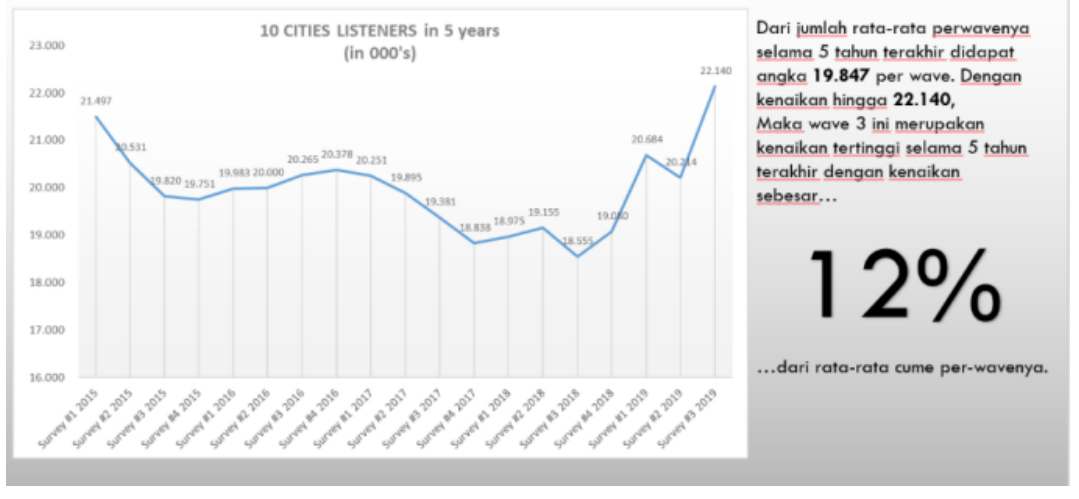

Graph 1. Growth Radio in Indonesia

(Source: Nielsen Listenership Study wave 32019 (Internal Data Delta FM)

According to a survey conducted by Nielsen in 2017, there are several reasons why people still listen to the radio, including $45 \%$ not wanting to feel alone or lonely, because the choice of songs is $44 \%$, fighting boredom is $40 \%$, new song releases are $32 \%$, and the last to hear religious lectures as much as 25\%. The Radio Audience Measurement (RAM) survey in the fourth quarter of 2017 still places radio as one of the people's choices. The average person in urban areas spends 130 minutes a week listening to the radio.

According to Nielsen's RAM survey results regarding the measurement of radio hearing of 8,400 respondents aged ten years and over, Nielsen's Audience Measurement Ratio data for the third quarter of 2016 shows that radio listening time per week seems to be growing from year to year. In 2014, radio listeners spent 16 hours listening to the radio per week; this continued to 
increase in 2015 (16 hours 14 minutes per week) and 2016 (16 hours 18 minutes). Furthermore, in 2017 (15 hours 10 minutes), especially for Jogja, Semarang, and Solo, the average is 15 hours 17 minutes per week (Nielsen, 2017).

The presence of digital technology and internet technology has also been adopted by audio media such as radio. The radio broadcasting system, which was initially analog, has changed the radio to a digital broadcasting system. Current technological advances make the media business proliferate, so radios are required to be able to adapt in the digital era in order to be able to maintain their existence. The development of the digital era is currently an opportunity and a threat to radio stations in Indonesia. The opportunity from this digital era is that it can increase the reach of radio listeners, but this makes radios have to pay attention to program content, develop creativity and innovate. Radio as an entertainment and information industry needs to be managed more professionally. The measure that this business must achieve is financial success and needs to be accompanied by the ability to show its existence in carrying out its function as a radio that can be used as a role model, social control, credibility, trendsetter, and idealism.

According to Robert McLeish, as quoted by Masduki (Masduki, 2004, pp. 26-27), the popular types of radio are (1) public service stations: radios that have and serve the public interest nationally; (2) commercial station: privately-owned radio for commercial gain; (3) government station: government radio used for public purposes; (4) government-owned station: government radio that is entirely used for propaganda; (5) institutional ownership station: radio owned by mass organizations, campuses, and NGOs; (6) community ownership: small community radio in a village."

According to Broadcasting Act no. 33/2002, three forms of radio may operate in Indonesia: (1) public broadcast radio, namely RRI; (2) commercial broadcast radio; and (3) community broadcast radio. The rapid development of digital media does not make the radio business just die. On the contrary, the presence of radio will always be in the hearts of its listeners. In Indonesia, there are more than 900 radios. Along with these developments, the types of radio are very diverse, both in terms of ownership and funding. Since the late 1990s, many radios are managed in one media group, with various radio formats in one group. Examples of these media groups include:: MNC (Radio Trijaya, Global Radio, Woman Radio), MRA (Hard Rock FM, I-radio, Traxx FM), Ramako Grup (Lite FM, Mustang, Kiss, Batam, dan Zoo), Masima Radio Network (Prambors FM, Bahana FM dan Delta FM), and others. 
The emergence of these private commercial radios has added to the splendor of the media business in various cities in Indonesia. The competition is not only in the metropolis but also in other cities, such as Yogyakarta.

Radio growth in Yogyakarta itself is quite rapid. More than 80 radio stations in Yogyakarta, including government radio, community radio, and commercial/private radio. In addition, there are several private radio stations based in Jakarta with networks in Yogyakarta, such as Prambors, Sonora FM, Global FM, I-Radio, MNC Trijaya FM, and Delta FM. The network radios compete with local radios in this city. Looking at a deeper analysis of radios in Yogyakarta, some have almost the same format and target market, which will undoubtedly tighten radio competition in maintaining their existence. Here we can see the rating of radios in Yogyakarta according to AC Nielsen:

Tabel 1. Data of Radio Rating in Yogyakarta

\begin{tabular}{|c|l|r|r|r|r|r|r|}
\hline W3 Rank & Market: YOGYAKARTA & Cume W3 & Cume W2 & GAP CUME & T.S.L. W3 & T.S.L. W2 & GAP T.S.L \\
\hline 1 & POP FM & 433 & 384 & 49 & 5,5 & 5,18 & 0,32 \\
\hline 2 & MBS FM & 334 & 332 & 2 & 7,33 & 7,32 & 0,01 \\
\hline 3 & RETJOBTG & 332 & 301 & 31 & 6,32 & 6,42 & $-0,1$ \\
\hline 4 & PERSATUAN & 253 & 271 & -18 & 5,21 & 5,05 & 0,16 \\
\hline 5 & GCD FM & 198 & 205 & -7 & 6,2 & 5,1 & 1,1 \\
\hline 6 & YASIKA FM & 163 & 167 & -4 & 2,29 & 3,1 & $-0,81$ \\
\hline 7 & PRAMBORS & 137 & 126 & 11 & 7,15 & 6,46 & 0,69 \\
\hline 8 & UTY MEDARI & 107 & 103 & 4 & 2,39 & 2,57 & $-0,18$ \\
\hline 9 & PRO1 & 84 & 53 & 31 & 3,13 & 2,17 & 0,96 \\
\hline 10 & ARMA11 & 80 & 83 & -3 & 4,49 & 3,26 & 1,23 \\
\hline 11 & KONCOTANI & 71 & 63 & 8 & 5,35 & 4,57 & 0,78 \\
\hline 12 & PRO2 & 69 & 68 & 1 & 2 & 6,01 & $-4,01$ \\
\hline 13 & JOGFAM & 59 & 71 & -12 & 1,48 & 1,57 & $-0,09$ \\
\hline 14 & PRO3 & 57 & 65 & -8 & 3,27 & 3,33 & $-0,06$ \\
\hline 15 & BEST FM & 57 & 44 & 13 & 4,41 & 4,09 & 0,32 \\
\hline 16 & I-RADIO & 51 & 58 & -7 & 3,29 & 3,37 & $-0,08$ \\
\hline 17 & DELTA FM & 51 & 65 & -14 & 8,07 & 4,34 & 3,73 \\
\hline 18 & SWADESI & 51 & 67 & -16 & 7,14 & 6,46 & 0,68 \\
\hline 19 & RAKOSA & 49 & 39 & 10 & 4,4 & 3,26 & 1,14 \\
\hline 20 & VEDAC FM & 48 & 58 & -10 & 5,16 & 4,07 & 1,09 \\
\hline 21 & KOTAPERAK & 46 & 58 & -12 & 2,4 & 4,16 & $-1,76$ \\
\hline 22 & SWARAGAMA & 46 & 46 & 0 & 6,08 & 5 & 1,08 \\
\hline 23 & EMCFM & 45 & 66 & -21 & 3,57 & 2,47 & 1,1 \\
\hline 24 & GERONIMO & 44 & 49 & -5 & 5,36 & 3,49 & 1,87 \\
\hline 25 & SKENA & 42 & 37 & 5 & 5,33 & 5,41 & $-0,08$ \\
\hline
\end{tabular}

(Source: Nielsen Listenership Study wave 3, 2019)

From the data above, it can be seen that in wave two and wave three radios based on cumulative total listeners, the top-ranking is dominated by local radios. Meanwhile, network radios such as Delta FM are not at the top. However, compared to radios with the same segmentation and target market as Swaragama FM, Unisi FM has a superior position even though both radios are local radios and have been around for a long time in Yogyakarta. 
According to the data above, there is a Jogja Family radio with the same market segment, and its ranking is above Delta FM Radio Yogyakarta. However, the researcher prefers to discuss Radio Delta FM Yogyakarta because Delta FM radio is a private network radio capable of competing with local radios in Yogyakarta with its broadcast quality, listeners, and advertisers.

Radio Delta FM is one of the radio networks (radio networks) under the auspices of Masima Radio Network, the same as Radio Prambors and Bahana FM. Initially, Delta FM was developed as a radio targeting the adult listener segment with an age range of 35-45 years old, an established life, a high position in the company, government, and society. Most of the listeners are Jakarta's A-B social class who have entered the phase of a calm but well-established lifestyle. In 1993-2011, Delta FM served listeners by playing golden memories, sweet songs combined with jazz music blocking and classical music inserts.

Then in December 2011, Delta FM made a significant change and improvement by carrying out a new broadcast concept. It was done by playing the best and most good songs to the ears of the target market aged 30-39 years with social-economic status (SES), namely A, B, and C+. At that time, Delta FM carried the Adult Contemporary (A.C.) Radio format, by playing easy listening songs from the 90 s, early 2000 s to songs that were hit, were packaged into a new tagline, "100\% Great Song". Currently, Delta FM is rejuvenating its target market to 25-34 years old with upper and middle-class social, economic status (SES). Moreover, Delta FM changed the format to Hot Adult Contemporary (Hot A.C.) Radio, with more dynamic songs from the '90s, early 2000's to the latest songs while still using the tagline "100\% Lagu Enak" (Delta FM, 2021).

The tight competition between radios in Yogyakarta requires a radio to have a strategy to maintain its existence. Competition forces companies to apply different marketing concepts from other companies to continue advancing (Prisgunanto, 2012). The strategy that needs to be implemented must be focused on maintaining and increasing listener loyalty to get a position in the listener's heart. In managing broadcast media, marketing communication strategies are very important to determine how a broadcast media will be formed and survive in the media industry's competition. Although it plays an important role, strategies in marketing communications are often not prioritized by companies. Marketing is not the same as trading because, in marketing, it is not just selling. Many do not realize that implementing the right marketing strategy will substantially affect the company or business that is being built (Prisgunanto, 2012).

There has been some research on the marketing communication strategy. However, most of the research on the radio marketing strategy focused on how to increase listeners. This is a piece of evidence in the research (Anastasia \& Machmud, 2020; Yunita, 2017). In addition, some 
research focused on developing radio programs as part of marketing strategy (Rusdi, 2011). However, these studies gave little attention to how the radio developed a marketing communication strategy using the S-T-P approach. It is the gap that this research attempted to fill.

The media's marketing communication strategy will always be associated with media marketing, namely Segmentation, Targeting, and Positioning (S-T-P). S-T-P is crucial to determine a marketing communication strategy to market a media company, one of which is radio. In addition, market analysis is needed so that the planning process can be carried out carefully. These stages make the media marketing communication process run smoothly and successfully.

Media marketing on the radio is considered vital because it can increase audience interest in listening to radio broadcasts and help radios survive in media competition. In maintaining the existence and tight competition in the radio media business in Yogyakarta, Radio Delta FM has thought about what marketing communication strategies they use to effectively and on target. This is why the researcher wants to know the marketing communication strategy carried out by Delta FM Radio in maintaining its existence in the Special Region of Yogyakarta.

\section{Method}

The qualitative research method was used in this study. According to Shank, qualitative research is "a type of systematic empirical inquiry into meaning" (Shank, 2006, p. 5). Qualitative research is a scientific method of gathering non-numerical data (Babbie, 2016). This type of research can provide a wide range of qualitative data with detailed descriptions and nuanced descriptions. In some cases, this type of data is more valuable than simply stating the amount or frequency numerically. Qualitative methods are used to answer questions about experience, meaning, and perspective, usually from the participant's point of view (Hammarberg et al., 2016). Guba and Lincoln (2005) define qualitative research as taking an interpretive and naturalistic approach. The research investigates things in their natural environment, attempting to comprehend or interpret phenomena in the context of meaning that people assign to them.

The subject of this study is Delta FM Jogja's marketing communication strategy. In this study, data were gathered through observation, interviews, and documentation. Data reduction, data display, conclusion drawing, and verification were all part of the data analysis. Meanwhile, the data in this study's validity is defined as credibility, transferability, dependability, and confirmability.

\section{Discussion}

A. Research Result

Planning 
In planning a marketing communication strategy, three aspects are always associated with media marketing: Segmenting, Targeting, and Positioning (S-T-P). Delta FM radio is also in the early stages of planning a marketing communication strategy to identify Segmenting, Targeting, and Positioning.

\section{Analysis of Marketing Communication}

Radio Delta FM analyzes internal and external factors that can be seen through analysis that includes situations, conditions, circumstances, events, and influences within and around the company.

The internal analysis consists of strengths and weaknesses, while external analysis consists of opportunities and threats. The number of local and networked radios in Yogyakarta, of course, makes competition in the radio industry quite fast. Each radio certainly has its image following its target market. However, it certainly still raises competition among radios with a similar or almost the same target market.

The following is the rating data based on the results of the AC Nielsen Wave 2018 and Wave 2019 surveys:

Table 1. AC Nielsen survey rating data

\begin{tabular}{|c|c|c|c|c|c|c|c|c|c|c|c|c|c|c|c|c|c|}
\hline \multirow{2}{*}{ UNIT } & \multirow{2}{*}{ INDEX } & \multicolumn{8}{|c|}{2018} & \multicolumn{8}{|c|}{2019} \\
\hline & & \multicolumn{2}{|c|}{ w1 } & \multicolumn{2}{|c|}{ W2 } & \multicolumn{2}{|c|}{ W3 } & \multicolumn{2}{|c|}{ W4 } & \multicolumn{2}{|c|}{ W1 } & \multicolumn{2}{|c|}{ w2 } & \multicolumn{2}{|c|}{ W3 } & \multicolumn{2}{|c|}{ W4 } \\
\hline \multirow{3}{*}{ DJOG } & Rank & 15 & & 14 & & 12 & & 10 & & 12 & & 15 & & 17 & & 22 & \\
\hline & Cume & 58 & $-18 \%$ & 61 & $5 \%$ & 62 & $2 \%$ & 68 & $10 \%$ & 74 & $9 \%$ & 65 & $-12 \%$ & 51 & $-22 \%$ & 45 & $-12 \%$ \\
\hline & TSL & 5.44 & $3 \%$ & 5.44 & $0 \%$ & 5.48 & $1 \%$ & 5.23 & $-5 \%$ & 6.53 & $25 \%$ & 4.34 & $-34 \%$ & 8.07 & $86 \%$ & 8.21 & $2 \%$ \\
\hline \multirow{3}{*}{ YASIKA } & Rank & 6 & & 6 & & 6 & & 6 & & 6 & & 6 & & 6 & & 6 & \\
\hline & Cume & 199 & $6 \%$ & 158 & $-21 \%$ & 153 & $-3 \%$ & 133 & $-13 \%$ & 151 & $14 \%$ & 167 & $11 \%$ & 163 & $-2 \%$ & 165 & $1 \%$ \\
\hline & TSL & 2.22 & $3 \%$ & 2.28 & $3 \%$ & 2.5 & $10 \%$ & 2.55 & $2 \%$ & 3.16 & $24 \%$ & 3.1 & $-2 \%$ & 2.29 & $-26 \%$ & 2.31 & $1 \%$ \\
\hline \multirow{3}{*}{ I RADIO } & Rank & 17 & & 16 & & 13 & & 13 & & 19 & & 17 & & 16 & & 15 & \\
\hline & Cume & 53 & $43 \%$ & 47 & $-11 \%$ & 59 & $26 \%$ & 57 & $-3 \%$ & 46 & $-19 \%$ & 58 & $26 \%$ & 51 & $-12 \%$ & 63 & $24 \%$ \\
\hline & TSL & 19.16 & $9 \%$ & 19.4 & $1 \%$ & 13.56 & $-30 \%$ & 6.41 & $-53 \%$ & 3.4 & $-47 \%$ & 3.37 & $-1 \%$ & 3.29 & $-2 \%$ & 2.56 & $-22 \%$ \\
\hline \multirow{3}{*}{ UTY } & Rank & 43 & & 43 & & 43 & & 19 & & 8 & & 8 & & 8 & & 9 & \\
\hline & Cume & 0 & $-100 \%$ & 0 & $0 \%$ & 0 & $0 \%$ & 39 & $39 \%$ & 84 & $115 \%$ & 103 & $23 \%$ & 107 & $4 \%$ & 107 & $0 \%$ \\
\hline & TSL & 0 & $-100 \%$ & 0 & $0 \%$ & 0 & $0 \%$ & 3.12 & $3 \%$ & 2.5 & $-20 \%$ & 2.57 & $3 \%$ & 2.39 & $-7 \%$ & 3.15 & $32 \%$ \\
\hline \multirow{3}{*}{ MEDARI } & Rank & 18 & & 20 & & 18 & & 32 & & 31 & & 34 & & 32 & & 34 & \\
\hline & Cume & 52 & $0 \%$ & 42 & $-19 \%$ & 42 & $0 \%$ & 0 & $-100 \%$ & 0 & $0 \%$ & 0 & $0 \%$ & 0 & $0 \%$ & 0 & $0 \%$ \\
\hline & TSL & 2.1 & $-3 \%$ & 2.19 & $4 \%$ & 2.2 & $0 \%$ & 0 & $-100 \%$ & 0 & $0 \%$ & 0 & $0 \%$ & 0 & $0 \%$ & 0 & $0 \%$ \\
\hline \multirow{3}{*}{ JOG FAM } & Rank & 10 & & 12 & & 17 & & 14 & & 13 & & 10 & & 13 & & 19 & \\
\hline & Cume & 92 & $-17 \%$ & 67 & $-27 \%$ & 51 & $-24 \%$ & 54 & $6 \%$ & 70 & $30 \%$ & 71 & $1 \%$ & 59 & $-17 \%$ & 48 & $-19 \%$ \\
\hline & TSL & 4.27 & $5 \%$ & 5.26 & $23 \%$ & 3.19 & $-39 \%$ & 2.46 & $-23 \%$ & 2.11 & $-14 \%$ & 1.57 & $-26 \%$ & 1.48 & $-6 \%$ & 1.31 & $-11 \%$ \\
\hline
\end{tabular}

(Source: Internal Data Delta FM) 
According to an AC Nielsen survey on i-listener data, Radio Delta FM Yogyakarta listeners in 2019 decreased by $9 \%$ for each wave, but it enters wave 1 in 2020, the listenership trend increased by $27 \%$.

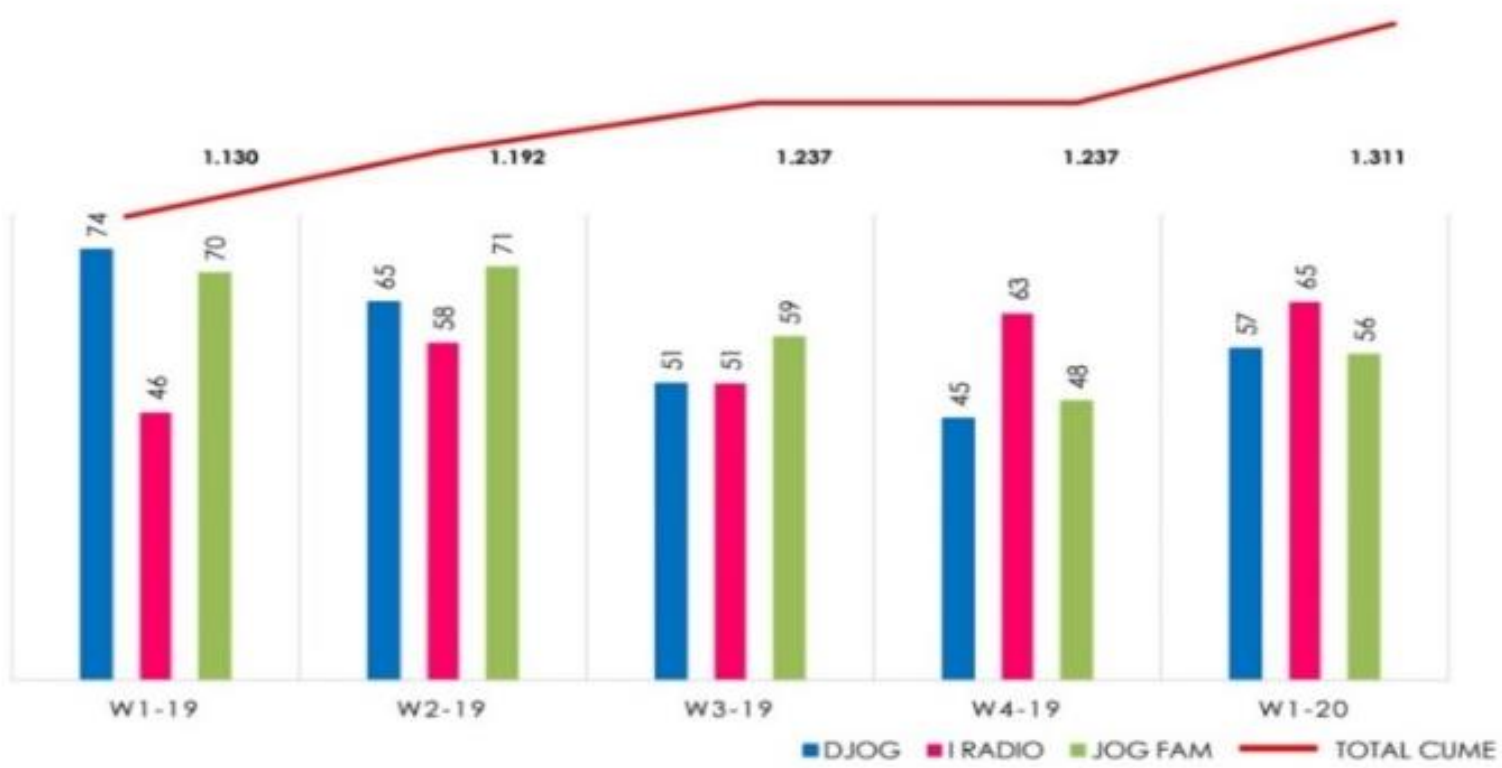

Tren listenership radio Delta FM pada tahun 2019 cenderung negatif, tercatat rata-rata menurun $9 \%$ setiap wavenya atau menurun $9 \%$ bila dibandingkan dengan tahun 2018 . Namun memasuki wave 1 2020 , tren listenership Delta FM kembali positif, meningkat $27 \%$ dibandingkan wave sebelumnya.

\section{Graph 1. Listenership Delta FM Yogyakarta} Source: Delta FM Yogyakarta

Here are the reasons listeners listen to Radio Delta FM Yogyakarta, based on a survey by AC Nielsen:

Table 2. Top 5 Reason to Listen Delta FM Yogyakarta, AC Nielsen

\begin{tabular}{|l|r|r|r|r|r|r|r|r|}
\hline \multicolumn{1}{|c|}{ DELTA JOG } & Survey \#3 2019 & Survey \#2 2019 & Survey \#1 2019 & Survey \#4 2018 & Survey \#3 2018 & Survey \#2 2018 & Survey \#1 2018 \\
\hline BORED OF CD/CSSTE & 0 & 0 & 1 & 2 & 2 & 1 & 1 \\
\hline FAVORITE SHOW & 13 & 10 & 16 & 14 & 11 & 14 & 14 \\
\hline FAVORITE SONGS & 30 & 31 & 44 & 45 & 35 & 41 & 37 \\
\hline FUNNY BROADCASTER & 13 & 9 & 14 & 19 & 11 & 12 & 13 \\
\hline GOOD BROADCASTER & 8 & 5 & 7 & 7 & 6 & 5 & 5 \\
\hline GOOD FREQ RECEPTN & 4 & 5 & 11 & 17 & 20 & 19 & 23 \\
\hline INFORMATV BRDCSTR & 6 & 7 & 9 & 6 & 9 & 6 & 5 \\
\hline INTERESTNG BRDCSTR & 5 & 5 & 6 & 6 & 6 & 4 & 5 \\
\hline LATEST NEWS & 20 & 19 & 30 & 25 & 20 & 17 & 15 \\
\hline LESS TALK BRDCSTR & 0 & 0 & 0 & 1 & 4 & 4 & 4 \\
\hline NEW RELEASE SONGS & 23 & 25 & 33 & 35 & 27 & 36 & 29 \\
\hline NOT FEELING LONELY & 42 & 59 & 62 & 60 & 49 & 44 & 43 \\
\hline NOT HAVE TAPE/CD & 0 & 0 & 0 & 0 & 0 & 0 & 6 \\
\hline OLDIES SONGS & 12 & 10 & 19 & 20 & 16 & 21 & 12 \\
\hline OVERCOME BOREDOM & 30 & 37 & 44 & 36 & 31 & 35 & 31 \\
\hline RELIGIOUS PREACH & 15 & 17 & 21 & 17 & 19 & 27 & 27 \\
\hline SLEEPING LULLABY & 11 & 9 & 9 & 10 & 7 & 5 & 9 \\
\hline STRESS IN TRAVEL & 5 & 5 & 7 & 9 & 5 & 14 & 15 \\
\hline SOFT NEWS & 17 & 13 & 23 & 17 & 12 & 17 & 16 \\
\hline TRAFFIC INFO & 0 & 4 & 5 & 6 & 6 & 3 & 6 \\
\hline OTHER & 6 & 7 & 8 & 0 & 0 & 0 & 0 \\
\hline
\end{tabular}

(Source: Internal Data Delta FM) 


\section{Implementation of Marketing Communication Strategy}

There are five elements of the marketing communication mix: Advertising (Advertising), Sales Promotion (Sales Promotion), Public Relations (Public Relations), Personal Selling (Personal Selling), and Direct Marketing (Direct Marketing).

Delta Yogyakarta cooperates with Tribun Jogja media and Bernas Daily to advertise in newspapers. In addition, Delta FM also promotes its radio by placing advertisements in hangout places such as malls, cafes, or restaurants. For example, Delta FM Yogyakarta collaborated with Legend Coffee to place a Delta FM banner to promote themselves to legend coffee visitors.

Sales promotions carried out by Delta FM are by making quizzes on specific broadcast programs to attract listeners, then from these quizzes, listeners can get prizes in the form of cash or shopping vouchers. In addition, Delta FM Yogyakarta conducts sales promotions to advertisers, and the sales team conducts sales promotions to encourage advertisers to advertise their products immediately. The PR team of Delta FM gave a press release to the press to report what Delta FM was doing to get a good image for the public. In addition, Delta FM cooperates with event organizers by becoming a media partner for the event, such as seminars, music concerts, and sports activities.

Radio Delta FM conducts personal selling effectively and efficiently to target the target market. Delta FM radio makes personal sales by providing what listeners want to make listeners continue to listen to Delta FM. Regularly the team from Delta FM will survey their listeners to find out what they present to listeners like or not.

Personal Selling that Delta FM Yogyakarta carries out is by communicating directly with listeners. In this case, Delta FM Yogyakarta and other network units always conduct periodic surveys about Delta FM's music and broadcast content.

Communication between sellers and buyers is assisted by media such as e-mail, fax, internet, etc. In addition, direct marketing is done to build relationships with buyers. In its direct marketing activities, Radio Delta FM utilizes various channels to reach its listeners.

\section{Marketing Communication Evaluation Strategy}

Delta FM radio has strengths that can be used as a supporting factor in implementing marketing communication strategies. These supporting factors include:

1. Positive image of the company

Delta FM introduces itself with a positive image to the audience. Delta FM radio with an image that is a well-known network radio with eight network radios spread across Indonesia makes it easier for him to build a good image. Apart from being a Radio Delta FM, he is also a member of 
the radio group Masima Radio Network and Radio Prambors, Radio Female, and Radio Bahana. It will undoubtedly create a positive image for Delta FM.

\section{Reliable Brand Manager}

In Marketing Communication at Radio Delta FM, the Brand Manager has a vital role in building Brand Delta itself. In this case, assisted by the Promotion Assistant Manager and Content Assistant Manager, the marketing communication strategy can work well. A reliable team at Delta FM will help the entire Delta FM network radio in Indonesia. This is because the central Delta FM has regulated the implemented system, both in programs and promotional activities.

3. Organized system from the center

Radio Delta FM is a network radio spread in 8 regions in Indonesia, and its center is in Jakarta. The supporting factor for network radio is that the broadcast system and its promotional activities have been regulated by the center, so that the network radio only needs to be carried out according to the protocol from the central Delta FM.

The central Delta FM monitors all activities carried out by its network radio by communicating with the Operational Manager of each network radio unit. At the beginning of every year, the central Delta FM team will visit each radio network to hold meetings and direct what needs to be done for the next year according to the planning proposals that have been made. It will undoubtedly facilitate running the marketing communication strategy because the central Delta FM has regulated the system.

\section{Different broadcasters}

In the case of Broadcasting, the broadcaster is a manifestation of each guided program. Therefore, Delta FM chooses broadcasters known by the public to attract listeners' attention and make Delta FM Yogyakarta a radio broadcasting that is a "star" and makes it different from other radio stations in Yogyakarta.

Our talent is different from other competitors. We dare to provide stars in the morning. Meanwhile, Jogja local radio still uses local broadcasters. We put them there hoping that they can trigger playing with 'people from Indonesia know them' without introducing this talent anymore. So that the broadcaster can distribute the content that we want to try to give to listeners (interview with Content Assistant Manager Nataya Kaligis)

In addition, broadcasters must also build closeness with listeners through the listener's greeting "Sobat Delta" or a personal greeting by mentioning the listener's name. Closeness to listeners can be done through telephone connections, SMS, Whatsapp, or through social media owned by Delta FM. By interacting with the listener, the listener will feel closer so that the listener can actively interact. This contributes to Delta FM Radio's marketing communications strategy's 
success in sustaining its existence because it is the broadcaster's role to attract listeners' attention via the program.

\section{Have a good track record}

So far, the track record of Radio Delta FM Yogyakarta is quite good. As a radio network for young adults, Delta FM still has a pretty good rating and can compete with other radio stations in Yogyakarta. That way, listeners will continue to listen to Delta FM, and advertisers will continue to advertise on Delta FM.

\section{Have a Featured Broadcast Program}

A broadcast program is the selling point of a radio marketer in offering their products. Most of the programs broadcast by Delta FM are national broadcast programs, and local broadcasts have a smaller broadcast portion. However, because Delta FM often plays old hits and new songs, listeners continue to listen to Delta FM. The main programs of Delta FM Radio are Asri Nino In the Morning, Fun Afternoons, Delicious Song Zone, and Love Song Stories.

\section{Following the Times}

Radio Delta FM realizes that the development of the times, especially in information technology, helps develop the radio industry. Therefore, Delta FM has utilized various digital platforms and possible to support promotions and interact with listeners. In addition, Delta FM also sees the times and launches a streaming radio application, namely Delta Channel, which is tailored to the needs of today's society. Because through the Delta Channel application, users can listen to the radio and perform other activities such as shopping online, reading news, planning trips, etc. Keeping up with the times certainly helps Delta FM reach its listeners and make its marketing communication strategy a success.

In addition to supporting factors, Delta FM Radio also encountered or experienced several obstacles in carrying out marketing communication strategies. These obstacles become an obstacle factor in achieving the goals expected by Radio Delta FM. These obstacle factors are known from interviews conducted with the Assistant Operational Manager of Delta FM, Rama Pratyaksa.

"Surely, there are obstacles in the implementation of this Marketing Communication. The most obvious thing is the lack of human resources here. Because we have two radios here, there is Delta FM and Prambors. So sometimes we miss the timeline because sometimes we are working on Prambors events. Delta is also on time who is close. So then not all events, promotional activities that can be done in Jogja."

\section{Human Resource Limitation}

Delta FM Yogyakarta has fewer teams than other radios. This is because all activities are regulated or monitored from the central Delta FM. So at Delta FM Yogyakarta, all the listeners have 
to do is carry out what has been planned from Delta FM Center. In addition, the Delta FM team also serves as an administrator for Prambors radio, a radio from the same group, Masima Radio Network. For this reason, Delta FM and Prambors FM use relatively the same marketing communication strategies, both from broadcast programs and promotional activities. However, this can be an obstacle because few Human Resources have to divide their focus into two jobs.

Although planning activities, both promotional activities, on-air and off-air programs, have been determined. Due to the lack of human resources, it becomes an obstacle to implementing marketing communication strategies at Delta FM Yogyakarta.

Delta FM organization is the simplest. There is only one Operational Manager, only one Operational Assistant Manager, and only one finance. However, here we have two radios, Delta and Prambors. It is straightforward because we are just implementing what the center has given us. It is just that sometimes it is a bit tight because there is a concurrent schedule between Delta and Prambors, so in the end, there will be something missing in the timeline, it has shifted slightly from what it should be, so this is it. (Interview with Assistant Operational Manager, Rama Pratyaksa)

\section{Intense competition}

The inhibiting factor faced by Delta FM Yogyakarta Radio is the large number of radio competitors in Yogyakarta. Although Delta FM has a decent rating in radio competition in Yogyakarta, the number of radios that also have almost the same music format may be an obstacle in implementing marketing communication strategies.

10. National content is too domineering

Delta FM Yogyakarta is a network radio, the broadcast program owned by Delta FM Yogyakarta is also an indication broadcast from the central Delta FM. this is because Delta FM Yogyakarta does not have local broadcasters. Local broadcasts only contain feature news or news that is currently hot in Yogyakarta. So that information related to local news is not conveyed too much in Delta FM Yogyakarta. So the broadcast style is undoubtedly more inclined to the broadcasting style of Jakarta than the broadcasting style of local radios from Yogyakarta.

\section{Steps in Troubleshooting}

In dealing with the obstacles that exist, of course, efforts need to be made to deal with them. This effort is made so that obstacles do not reappear so that they do not become obstacles to implementing marketing communication strategies. The steps taken by Radio Delta FM are as follows:

1. Carry out continuous improvement

To overcome obstacles, Radio Delta FM continues to make continuous and continuous improvements. The survey was also made based on the survey to make it more in line with the 
planning target. This is done to minimize problems or obstacles that arise. Moreover, that way, Delta FM Radio can provide the best and can maintain its existence.

2. Holding work meetings and coordination

Every year, Delta FM Radio holds a working meeting which is carried out together with the central Delta FM Radio and other Delta FM Network Radios. This is done to discuss the work plan for delta FM radio and discuss the obstacles that arise and are faced by each radio network. Furthermore, in addition to the central radio, Radio Delta FM Yogyakarta also regularly holds internal meetings with the Delta FM Jogja team to discuss the problems they are currently facing. Through the meetings held, the points that become obstacles will be identified, and then the team will find solutions in dealing with these obstacles so as not to cause significant losses and monitor the solutions that have been determined.

"So, usually starting from October to December, we are already busy planning for the next year, Delta FM, what to do, whether nationally or in Jakarta, we have been thinking about since the end of that year. Then, towards the end of the year, we will floor our work plan for the next year regarding the Delta network in other cities. From Jakarta, we will hold meetings in each city." (Interview with Brand Manager Delta FM, Evan Perdana)

3. Conducting program evaluations that have been carried out

After the program is implemented, it is necessary to evaluate the program. The evaluation carried out by Delta FM Radio aims to find out the advantages and disadvantages of the previous program. By doing this, the program that will be implemented in the future can be better than before, and the same error will not occur related to the obstacles encountered.

4. Strengthen the positive image

Strengthening the company's positive image is one of the efforts to overcome obstacles in marketing communication activities. The image of a company is the essential thing that must be maintained and maintained in an organization. If the company's image is destroyed, the company must rebuild that image. Rebuilding an image will be more complex than building an image from scratch. Radio Delta FM realizes this as a medium that relates to the interests and needs of the public, so it is necessary to strengthen a positive image and maintain that image.Delta FM Marketing Communication Strategy in the digital era

In Indonesia, many conventional radios have adapted to digital nowadays. They use the internet as a merging medium, giving rise to internet radio or streaming radio. Radio Delta FM is one of the networked radio stations in Yogyakarta that has adopted the radio digitization approach. In this case, Radio Delta FM utilizes streaming radio to expand its listeners' reach and maintain its existence. 
Internet radio or streaming radio is an audio broadcasting service that is transmitted over the internet. Therefore, radios that have streaming services can be heard globally. Listeners can enjoy radio streaming by using playing facilities provided by service providers on their official web. In addition, listeners can also use webcasts, such as Winamp, windows media player, iTunes, and so on, to access streaming radio.

B. Analysis

Radio Delta FM Yogyakarta has carefully planned its marketing communication strategy. Radio Delta FM carries out a marketing communication strategy to maintain its existence as a broadcast media. Before carrying out a marketing communication strategy, Radio Delta FM first carried out a plan. Planning is a goal of a marketing communication strategy to achieve sales targets. Planning is carried out so that the implementation or implementation of the marketing communication strategy is carried out as expected. The planning process regarding the marketing communication strategy is carried out by holding regular meetings at the central Delta FM and at the Delta FM radio network in other cities, including Yogyakarta.

In this study, the author uses the communication planning theory of Charles Berger to explain the marketing communication strategy planning process carried out by Delta FM Radio. Planning is a process of thinking about the action plan that will be passed. Communication has an essential role in achieving goals. Planning will produce the expected goals. Therefore, communication planning must be adequately prepared so that the implementation goes as expected. Charles Berger's Planning Theory assumes that a vital goal will undoubtedly affect the plan. Concerning this theory, Radio Delta FM has formulated a goal before planning.

Radio Delta FM also carried out this strategic planning based on the knowledge possessed by the implementing actors. This knowledge comes from surveys conducted by both research institutions and internal surveys of Delta FM Radio. The research results that have been found are then used as a guide. Therefore, Delta FM radio has much knowledge to prepare the company's vision and mission, formulate strategic issues, and formulate development strategies. It means Radio Delta FM already knows what a media company has to prepare. Radio Delta FM has prepared several things that will later be used to maintain the continuity of the media. This knowledge includes current market and society conditions, package programs, selection of human resources, and strategies to face competition.

Radio Delta FM presents programs based on the needs of its listeners. First, through a coordination meeting from the content assistant manager team, program planning is carried out, then reunited with the promotion assistant manager and brand manager. Moreover, after that, it will 
be notified to the entire Delta FM radio network. The presentation of programs from Radio Delta FM is to entertain listeners by presenting music, providing information, and helping listeners have fun because of the increasingly heavy responsibilities of life. In making programs and promotional activities, Delta FM always conducts periodic surveys to find out the wishes of the listeners. The survey was obtained from the AC Nielsen survey and an internal survey conducted by Masima Radio Network and Delta FM. By doing so, Delta FM Yogyakarta implements a marketing communication strategy by observing and adapting to the times.

This process can be seen in how Delta FM responds to competition with other media, such as internet media. Delta FM radio sees the increasingly complex needs of the community by utilizing various social media as a means of interaction with listeners. In addition, Delta FM has also launched a streaming radio application that can be used to access other things such as shopping, reading news, or planning trips.

According to the researcher, planning in the marketing communication strategy carried out by Delta FM Radio is quite good if it is associated with Charles Berger's Communication Planning Theory. Although in its implementation, there must be adapted to the existing situation. This is because Delta FM Radio is a media company that provides services, not a company that sells products so that in carrying out marketing communication activities in terms of promotion, it can be done with cooperation in the form of barter or semi-barter. Thus, for example, business competitors such as Bli-bli.com, Ticket.com, Seekmi, Zemato, and GoLife used as partners to work together to achieve goals and obtain mutual benefits.

According to the author, the planning carried out by Delta FM Yogyakarta, which is related to the implementation of marketing communication strategy activities, has not been carried out optimally. This can be seen from the implementation of marketing communication strategies, namely sales promotion and direct marketing. Here it can be seen that the lack of human resources in the Delta FM Yogyakarta team has hampered promotional activities. Furthermore, the researcher discovered that the center's planned off-air programs were not carried out on time. Delta FM Yogyakarta's social media was underutilized, as evidenced by the low number of content uploads on social media.

According to the researcher, Delta FM Yogyakarta makes greater use of the work program established by the Delta FM Center. Delta FM Yogyakarta only follows through on what has been established. However, the results of the implementation are not always optimal. On the other hand, Delta FM Yogyakarta can survive in radio competition in Yogyakarta and maintain its existence in 
Yogyakarta through on-air broadcast programs, social media such as the official Instagram delta FM, and a website that has been regulated from the Central Delta FM.

Although several implementations of marketing communication strategies have not been implemented optimally at Delta FM Yogyakarta, of course, some things have been implemented well and are pretty compelling. The implementations are advertising (advertising), public relations (public relations), and personal selling (personal selling). Delta FM Yogyakarta always advertises in local print media such as Tribun Jogja, and Harian Bernas. In addition, it also collaborates with cafes to place banners or flayers for radio promotions. For public relations activities, Delta FM Yogyakarta maintains good relations with its business relations. Besides that, Delta FM Yogyakarta always conducts product publicity by becoming a media partner of an event organizer. This is a reciprocal benefit, so Delta FM often does it.

The marketing communication strategy implemented by Delta FM Yogyakarta has not been effective in maintaining its existence. Because the planned marketing communication strategy was not correctly implemented. According to the researcher, the lack of human resources at Delta FM Yogyakarta is one of the obstacles in achieving the objectives of the marketing communication strategy.

During this research, the researcher found that Radio Delta FM Yogyakarta and Radio Prambors Yogyakarta had the same management. This is because the marketing communication strategies, both broadcast programs and promotional activities, are relatively the same. It can be seen from the arrangement of regular programs owned by Delta FM and Prambors with the same characteristics. For example, Asri Nino In The Morning and Desta \& Gina In The Morning. In the two programs this morning, the selection of broadcasters with the same characteristics, namely Asri and Gina, who have shrill voices, was intended to wake, accompany, and encourage listeners in the morning.

The decision to combine the two radio managements based on Delta FM Pusat considerations, namely human resource efficiency, cost less and increased profit income. However, the execution was not running optimally, and this can be seen from the results of an interview with the Assistant Operational Manager of Delta FM Yogyakarta, who said that sometimes there was a missed timeline in the promotion process because the schedule of activities was close to Radio Prambors Yogyakarta. This makes the focus of workers in handling their work divided between Delta FM and Prambors.

In the face of radio competition in the digital era, Radio Delta FM expands the reach of its listeners by providing streaming radio facilities. Listeners can access radio streaming through Delta 
FM's official website and the Delta Channel application launched by Delta FM. This is done in addition to expanding the reach of listeners and expanding the advertiser's clientele. By utilizing digital media, Delta FM will be easier to promote, and listeners will be more accessible.

\section{Conclusion}

Based on the research results above, Radio Delta FM makes a mature marketing communication strategy to maintain its existence in Yogyakarta. The marketing communication strategy of Delta FM Yogyakarta is divided into three major stages. The stages are as follows: planning, implementation/implementation, and evaluation. First, Delta FM Yogyakarta evaluates the supporting and inhibiting factors in the marketing communication process. Then, these factors are used as guidelines for making adjustments to the planning and implementation of the following strategy. After that, the Delta FM Yogyakarta team can find solutions/steps to overcome the problems.

The marketing communication strategy of Delta FM Yogyakarta is created and regulated based on the planning of the central Delta FM (Delta FM Jakarta). The central Delta FM communicates with the operational manager of each radio network to coordinate so that each network can go hand in hand. They are equalizing the broadcast and promotion system, making job desk at Delta FM Yogyakarta not as many as radio in general. Delta FM Yogyakarta does not have local broadcasters because broadcast programs have been made from the center. For this reason, the broadcast system and promotional activities have been arranged so that the center will more easily monitor them. However, this could be one of the inhibiting factors because the national broadcast content is too dominating. With a more significant portion of national broadcasts, broadcasts are too Jakarta-centric (more information about Jakarta and Jakarta-style Broadcasting).

The research found that there is a shortage of human resources in Delta FM Yogyakarta. This is because the focus is divided between the management of Delta FM radio and Prambors Yogyakarta. Moreover, both radios are part of the media group Masima Radio Network. This makes the company structure of Radio Delta FM Yogyakarta the same as Radio Prambors. As a result, the management team is also the job desk for Delta FM and Prambors Yogyakarta. In addition, the study found that the strategy patterns of both programs and promotional activities carried out by the two radio stations had similarities. 


\section{References}

Anastasia, H., \& Machmud, S. (2020). Strategi Komunikasi Pemasaran Radio Maros FM dalam Meningkatkan Jumlah Pendengar. Journal of Communication Sciences (JCoS), 2(2), 7179.

Babbie, E. R. (2016). The Basics of Social Research. Cengage Learning.

Delta FM. (2021). DELTA FM - About Us. https://deltafm.net/pages/aboutus_page.php

Guba, E. G., \& Lincoln, Y. S. (2005). Paradigmatic Controversies, Contradictions, and Emerging Confluences. In The Sage handbook of qualitative research, 3rd ed (pp. 191-215). Sage Publications Ltd.

Hammarberg, K., Kirkman, M., \& de Lacey, S. (2016). Qualitative research methods: When to use them and how to judge them. Human Reproduction, 31(3), 498-501. https://doi.org/10.1093/humrep/dev334

Masduki. (2004). Menjadi Broadcaster Profesional. LKIS Toko Buku Online Buku-Buku LKiS Groups. http://www.lkis.co.id/produk-907-menjadibroadcasterprofesional.html

Nielsen, H. (2017). Predicting Secretory Proteins with SignalP. Methods in Molecular Biology (Clifton, N.J.), 1611, 59-73. https://doi.org/10.1007/978-1-4939-7015-5_6

Prisgunanto, I. (2012). Pengaruh Tingkat Kepercayaan Berkomunikasi di Jejaring Sosial Internet (Social Media) Terhadap Perilaku Beli Mahasiswa. Ultimacomm: Jurnal Ilmu Komunikasi, 4(1), 1-12. https://doi.org/10.31937/ultimacomm.v4i1.412

Romli, K. (2016). Komunikasi Massa. Gramedia Widiasarana Indonesia.

Rusdi, F. (2011). Strategi Komunikasi Pemasaran Program Interaktif di Media Radio. 1(3). http://jurnalaspikom.org/index.php/aspikom/article/view/23

Shank, G. D. (2006). Qualitative research: A personal skills approach (2nd ed). Pearson Merrill Prentice Hall.

Yunita, R. (2017). Strategi Komunikasi Pemasaran Dalam Mempertahankan Eksistensi Radio Dangdut Terdepan Di Jakarta (Studi Kasus Eksistensi Radio Cbb 105,4 Fm). Jurnal Komunikasi, 8(1), Article 1. https://doi.org/10.31294/jkom.v8i1.2116 
The Indonesian Journal of Communication Studies, Volume 14/ Nomor: 1/ 2021

Page: 57-74

P-ISSN: 1978-323X, E-ISSN: 2685-529

DOI: http://doi.org/10.31315/ijcs.v14i1.5075 